Vol. 5 (1996): 329-350.

\title{
Assessing the risks and uncertainties of regional crop potential under a changing climate in Finland
}

\author{
Timothy R. Carter', Riitta A. Saarikko' and Kai J. Niemi \\ Agricultural Research Centre of Finland, 'Office address: Finnish Meteorological Institute, \\ Box 503, FIN-00101 Helsinki, Finland
}

\begin{abstract}
Results are presented of a modelling study to estimate the regional suitability and potential productivity of selected crops in Finland under a changing climate. Model simulations were conducted across a regular $10 \mathrm{~km}$ grid over Finland for various cultivars of the following crops: spring wheat, barley, oats, potato and maize, and for two nematode pests and a fungal disease of potato. Models were run for both the present-day (1961-1990) climate and scenarios of future climate. Results are presented as maps. The main findings of the study are: (1) A warming of the climate induces shifts in the northern limit of cereal suitability of some $100-150 \mathrm{~km}$ per ${ }^{\circ} \mathrm{C}$. (2) Changes in climate and carbon dioxide concentration by 2050 are estimated to enhance average grain yields of present-day barley cultivars in all regions. (3) Under projected warming, the potential distribution of nematode species expands northwards and additional generations of some species are likely. The risk of late blight occurrence increases in all regions. (4) By 2050 grain maize could be cultivated reliably in favourable regions of southern Finland, and satisfactory yields obtained. (5) Uncertainties surround all estimates, including uncertainties in projections of future climate, model errors and assumptions and observational errors.
\end{abstract}

Key words: suitability, crop yield, spring cereals, maize, potato, late blight, nematodes, 2050 scenario

\section{Introduction}

It has been demonstrated in numerous studies that global climate change can have significant impacts on crop production in different parts of the world (e.g. Parry 1990, Rosenzweig and Parry 1994, Reilly et al. 1996). In Finland too, research suggests that increasing temperature and higher concentrations of carbon dioxide in the atmosphere can lengthen the growing season and enhance the productive potential of field crops (e.g. Kettunen et al. 1988, Hakala and Mela 1996, Kleemola and Karvonen 1996). These conclusions are largely based on two sources of information: (i) experiments with plants grown under controlled conditions and (ii) simulations with mathematical crop growth models. Such findings tend to be site specific, and usually fail adequately to describe geographical variations 


\section{AGRICULTURAL AND FOOD SCIENCE IN FINLAND}

\section{Carter, T. R. et al.: Assessing regional crop potential under a changing climate in Finland}

in crop response. However, knowledge about possible changes in the regional pattern of crop potential may be of great value to agricultural decision makers.

Several previous climate change studies in Europe have focused on changes in crop suitability, using simple models to delimit regions in which future agroclimatic conditions would be appropriate for successful crop cultivation. Studies have been reported of wheat (Kenny et al. 1993, Brignall et al. 1994, Bindi et al. 1993), maize (Carter et al. 1991a, Kenny and Harrison 1992a, Brignall et al. 1994); sunflower and soybean (Carter et al. 1991b), grapevine (Kenny and Harrison 1992b) and cauliflower (Kenny et al. 1993). Fewer studies have attempted to estimate regional crop productivity using mechanistic crop growth models. Some model site yields and attempt to scale up to the surrounding region or country using qualitative criteria (e.g. Wolf 1993, Wolf and van Diepen 1995; and, in a global study, Rosenzweig and Iglesias 1994) or using objective interpolation and extrapolation (e.g. Williams et al. 1988 in Canada; Rötter and van Diepen 1994, Davies et al. 1993). A small number have run simple crop growth models over a regular grid, using interpolated long-term mean climatological data as input (e.g. Leemans and Solomon 1993 at global scale, Jones and Carter 1993, Harrison et al. 1995). To our knowledge, no grid-based modelling studies have yet considered both the mean and the interannual variability of regional crop response to a changing climate. Variability of crop potential can be as important as the mean because it is a measure of the risk and reliability of crop production (Mearns et al. 1992, Semenov and Porter 1995).

In this paper, we present results of a study to estimate the regional suitability and potential productivity of selected crops in Finland under a changing climate. We demonstrate, for the first time, the application of crop models over a regular grid to evaluate changes not only in the mean but also the variability of regional crop potential. In addition, we provide an illustration of the changing pattern of damage potential from pests and diseases. Some of the major uncertainties of the approach are quantified and a number of future research needs identified.

\section{Methods}

\section{Geographical analysis system}

The approach adopted in the study employs a national-scale geographical analysis system in conjunction with crop-climate models (Carter and Saarikko 1996). The models, which range from simple agroclimatic indices to complex crop growth simulation models, are run using data organised in a network of 3827 grid boxes at $10 \times 10 \mathrm{~km}$ resolution across Finland.

Environmental data at this resolution have been obtained for climate, land cover and topography, but gridded soils data for Finland are not available. Regional agricultural data on cropped area and yields were also obtained to map the current production pattern and to validate the indices and models. A geographical information system, IDRISI, is used to combine the data and display the results.

Climatological data are for the baseline period 1961-1990, the standard reference used in the Finnish Research Programme on Climate Change (SILMU). Station data for each year of the period and for 30-year means have been interpolated to the $10 \mathrm{~km}$ grid by a kriging method (Henttonen 1991) at the Finnish Meteorological Institute (FMI). The data include monthly precipitation and monthly means of maximum, minimum and mean temperature and global solar radiation. Observed values of radiation were supplemented with values derived from observations of cloudiness and sunshine duration.

In addition, daily data were obtained from FMI for various climatic variables at individual meteorological stations in Finland. These data were used for model validation. An alternative source of daily climatological time series (for precipitation, mean temperature and cloudiness) was a stochastic weather generator, CLIGEN 


\section{AGRICULTURAL AND FOOD SCIENCE IN FINLAND}

Vol. 5 (1996): 329-350.

(Posch 1992, 1994, Carter et al. 1995). The parameters of CLIGEN were derived for all meteorological stations reporting daily data in Finland during the period 1961-1990. Daily time series can be generated for any point in Finland, by interpolation of the station parameters. Daily solar radiation values are derived from cloudiness amounts using empirical relationships established from site data.

\section{Model testing and application to the grid}

The models are described in the next section. Each model was subjected to conventional sensitivity testing, in order to evaluate possible sources of model uncertainty. Where possible, model outputs were validated against observations from experimental sites, variety trials, pest and disease observation networks and regional statistical sources. Particular attention was paid to the performance and applicability of models across the full range of environmental conditions currently found in Finland, to justify applying the models to the grid. Moreover, models were also tested for climatic conditions outside the range experienced in Finland, to assess their applicability for simulating effects of climate change.

The approach used to conduct model simulations over the $10 \mathrm{~km}$ grid varied between models. All models operate on a daily time step, but their input data requirements vary widely. Most of the models of crop and pest/disease development are based on measures of accumulated temperature, which can be evaluated to an acceptable accuracy using daily temperatures interpolated from mean monthly temperatures. However, several models are highly sensitive to the within-month daily variability of climate, especially precipitation. For these models, realistic daily data were required at each grid box. Where soil parameters were required, in the absence of gridded soil data the parameters of generic soil types were defined, and models were run for each soil type across the entire grid.

\section{Simulating a changed climate}

Climate changes were simulated by altering the baseline climatological data according to the SILMU climatic scenarios (Carter et al. 1995, Carter 1996). The basic scenario employed in all model simulations is SILMU policy scenario 1 (central "best guess") for 2050. However, some model runs have also been conducted for the range of scenario uncertainty, using SILMU policy scenarios 2 (low) and 3 (high), and for time horizons of 2020 and 2100 . These scenarios specify seasonal changes which are uniform over the whole of Finland. In addition, several runs have also explored variants of scenario 1, using the SILMU scientific scenarios 1a, 1b and 1c. These specify the regional pattern of change on a monthly basis, based on estimates from different global climate models. All SILMU climatic scenarios are accompanied by consistent scenarios of carbon dioxide concentration, which are required as inputs to some yield models (Carter 1996).

In the simulations reported here, the baseline climate at a future date has been adjusted according to each scenario by applying the same changes to all years of the baseline period. This approach treats the future climate as if it were in equilibrium. In reality, of course, the future climate is unlikely to be in equilibrium, but will be changing continually. However, exploratory crop model simulations indicate that removing the trend from the scenario climate does not significantly alter the crop response.

\section{Models}

Five different models or sets of models have been employed in the study. They are described briefly here, but all are documented in detail elsewhere. Their selection should not imply that they are any more appropriate for this application than other models - it merely indicates that a model was available for this study, and sufficient data 
Carter, T. R. et al.: Assessing regional crop potential under a changing climate in Finland

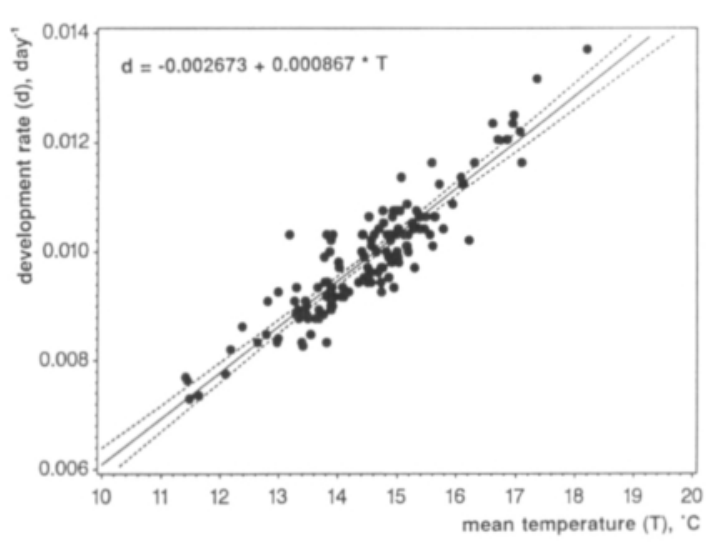

Fig. 1. Relationship between mean development rate $\left(\right.$ day $\left.^{-1}\right)$ and mean temperature $\left({ }^{\circ} \mathrm{C}\right)$ in spring wheat (cv. Ruso) for the phase sowing to yellow ripening. Broken lines are $95 \%$ confidence limits. (Data source: Official variety trials, Agricultural Research Centre of Finland)

could be obtained for model testing. Other models will be applied to the grid at a later date.

\section{Cereal development models}

Phenological models have been constructed to estimate the growing time and phasic development of spring-sown cereal cultivars (Saarikko and Carter 1996). Relationships were examined between environmental factors (temperature, precipitation and photoperiod) and phenological observations after sowing (heading and yellow ripening) at experimental stations in Finland during the period 1970-1990. Temperature alone was found to explain the course of phenological development, and a linear relationship was established between daily mean air temperature and daily development rate for all phases and cultivars (Figure 1). Models were constructed for three cultivars of wheat (Triticum aestivum), of barley (Hordeum vulgare) and of oats (Avena sativa) for the phases sowing to heading, heading to yellow ripening and the entire phase sowing to yellow ripening.

In order to apply the model to the grid, the beginning and end of a "favourable growing period" need to be defined. Sowing of spring cere- als was assumed to take place on the day when smoothed daily mean temperature exceeds $8^{\circ} \mathrm{C}$, based on sowing date information from the experimental sites. The end of the favourable growing period is defined by the date on which mean daily temperature falls below $12^{\circ} \mathrm{C}$. This date approximately corresponds to the $25 \%$ probability of first autumn frost occurrence in Finland as computed by Solantie (1987).

When estimating crop development across the Finnish grid, smoothed daily mean air temperatures were obtained from monthly means using the Brooks sine curve interpolation method (Brooks 1943). The development of each cultivar was computed for individual years during the 30 year baseline period and during 30 year periods corresponding to a range of SILMU scenarios.

\section{Barley yield simulation model}

Barley is grown widely in Finland, accounting for about $20 \%$ of the cultivated area in 1993 (Agricultural Information Centre 1994). Barley yields have been simulated using a process-based crop growth model, CropWatN, developed at the Department of Plant Production, University of Helsinki (Karvonen and Kleemola 1995). The model calculates crop growth and development on a daily basis as a function of global radiation, mean air temperature and precipitation. Simulations can be conducted either for potential production or for soil water and nitrogen limited production. The direct effects of increasing atmospheric $\mathrm{CO}_{2}$ concentration on plant photosynthesis are also computed. The main features of the model are described by Kleemola and Karvonen (1996), the only difference being a less detailed soil temperature scheme in the version used here than in their updated model.

The model was calibrated using detailed observations of climate, soils and the growth and development of barley (cv. Pomo) from experiments at Jokioinen during 1982-1987 (Ilola et al. 1988). Values of more than 30 parameters were required, and many of these were site spe- 
Vol. 5 (1996): 329-350.

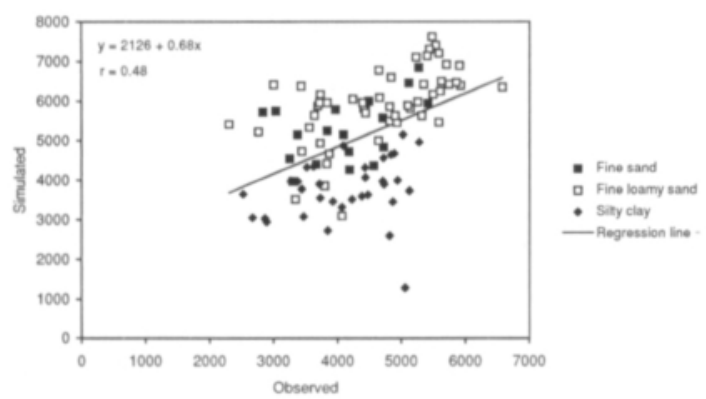

Fig. 2. Simulated vs observed grain yield in barley for three soil types at four sites in selected years during 1970-1990. Modelled phenology is fixed at observed dates (Data source: Official variety trials, Agricultural Research Centre of Finland)

cific, since they related to soil properties. A prior sensitivity analysis indicated that modelled yields could be highly sensitive to parameter values relating to the movement of water in the soil.

To test whether the model could be applied to other conditions in Finland, data on phenology, fertilizer application, soil type and yields were obtained for official variety trials at four experimental stations in different parts of Finland during the period 1970-1990. Since measured soil characteristics were not available, parameter values for the fine sand, sand loam and silty clay types reported from the sites were estimated based on published material (J. Kleemola, personal communication). The model was run using weather data from each site.

A comparison of simulated against observed grain yields at the four sites is given in Figure 2, classified by soil type. There is a positive relationship between the two $(r=0.48)$ although the scatter is quite large. Some of the discrepancies between the modelled and observed values are clearly systematic and related to soil type. This is not surprising, given that the precise nature of the soils at each site was not known. These results were encouraging enough, however, to justify applying the model at national scale.

In order to apply the model to the grid, two soil types were selected, representing a range of water holding characteristics: a heavy clay type, using the measured parameters from Jokioinen, and the fine sand type, using the same parameter estimates used in the validation exercise. Parameters for crop phenology were those reported for the Pomo cultivar by Saarikko and Carter (1996).

Daily temperature and radiation data were obtained from monthly data using the Brooks interpolation technique (Brooks 1943). The effect of using smoothed temperature and radiation data was evaluated in an earlier sensitivity analysis, and found to produce an overestimate of final yield compared with using observed daily values of about $19 \%$. This is to be expected since daily extremes of temperature and radiation, which inhibit growth, are not represented in the smoothed data.

Gridded monthly precipitation was allocated between days according to the frequency distribution of precipitation observed at Jokioinen during 1961-1990. Given the high sensitivity of the modelled yield to soil water, this technique produced the most realistic precipitation distribution of several methods tested.

Model runs were conducted for the 30 individual years of the 1961-1990 baseline and for a 30-year scenario climate representing 2050, using SILMU scenario 1 . The model was run at all grid boxes for unstressed (potential) conditions and for rainfed conditions on both soil types. Simulations were run for scenario temperature and precipitation changes alone, for elevated $\mathrm{CO}_{2}$ concentration (523 ppm) alone, and for these two conditions combined.

\section{Maize yield simulation model}

Maize (Zea mays) is a tropical crop occasionally grown for silage and sweet corn in Finland. Trials conducted in the 1970s in southern Finland suggested that with very early hybrid varieties a mature grain yield could be harvested twice in ten years, good quality silage material obtained six years in ten and a satisfactory crop eight years in ten (Pulli et al. 1979). Later work, at European scale, indicated that climatic warm- 


\section{AGRICULTURAL AND FOOD SCIENCE IN FINLAND}

Carter, T. R. et al.: Assessing regional crop potential under a changing climate in Finland

ing of $3-4^{\circ} \mathrm{C}$ would have the potential to shift the northern limit for economic yields of grain maize from northern Germany and central Poland, where it lies today, into southern Finland (Carter et al. 1991a, Kenny and Harrison 1992a).

The CERES-Maize model (Jones and Kiniry 1986) has been adopted in this study. It has been used in a number of previous climate change studies in different parts of the world (e.g. Rosenzweig and Iglesias 1994). Like CropWatN, CERES-Maize attempts to simulate the main processes of crop development and growth. It requires daily minimum and maximum temperature, global radiation and precipitation as inputs. A key requirement for running the model is the selection of parameters characterising the crop phenology and yield capacity. These were estimated for a short-season hybrid, based on information given by Pulli et al. (1979).

Model simulations with the CERES-Maize model were exploratory, and the only runs conducted to date have been for potential yields. They are thus independent of soil type and assume no water or nutrient stress. Gridded data on monthly climate were converted to daily values in the same way as for the barley model. Simulations were conducted for each year of the 1961-1990 baseline climate and for the climate estimated for 2050 under SILMU scenario 1. Effects of $\mathrm{CO}_{2}$ increase on crop growth were not modelled.

\section{Nematode models}

Simple models of two pests of potato (Solanum tuberosum) have been applied to the grid. One, the potato cyst nematode, is a troublesome pest at the present-day. The other, the Columbia rootknot nematode, could represent a serious threat in the future (Tiilikkala et al. 1995).

The potato cyst nematode (Globodera rostochiensis), is the most noxious pest in presentday Finnish potato production. This parasite is restricted in its range by temperature to southern and central Finland (Tiilikkala 1991). Its absence from northern Finland is a valuable as- set for the production of high quality seed potatoes. The northern limit of the nematode approximately coincides with an effective temperature sum (ETS) of 800 day-degrees above a base temperature of $5^{\circ} \mathrm{C}$, cumulated during the period with air temperatures exceeding $9^{\circ} \mathrm{C}$ (Tiilikkala, personal communication).

The Columbia root-knot nematode (Meloidogyne chitwoodi), is a newly discovered nematode pest in Europe (Tiilikkala et al. 1995). It has a wide host range and is well adapted to low temperatures. The nematode is a serious pest of potato in the Pacific Northwest of the USA, but has only recently been discovered in Europe, in the Netherlands. M. Chitwoodi can overwinter as eggs and juveniles. This pest, unlike $G$. rostochiensis, can produce multiple generations, the number dependent upon the soil temperature. An extra generation, especially late in the season, will result in a tremendous increase in population densities.

The model used here is again based on effective temperature sum above a base temperature of $5^{\circ} \mathrm{C}$, but cumulated in this case during the period with air temperatures exceeding $5^{\circ} \mathrm{C}$. The approximate day-degree requirements for different generations have been defined in a pest risk assessment by Tiilikkala et al. (1995).

Both nematode indices have been computed across the Finnish grid, using daily temperatures interpolated from the monthly means (as described above) for each of the 30 years of the baseline climate and for the baseline values adjusted according to a number of SILMU scenarios.

\section{Potato late blight model}

Potato late blight (Phytophthora infestans) is a damaging fungal pathogen that grows in the leaves and stems of the potato plant. It progressively kills the tissues and reduces the effective photosynthetic area of the plant. As a result, little assimilate is passed to the tubers and yield is reduced. The spores are dispersed by rain, and can initiate new infections on leaves or, if washed into the soil, on the developing tubers. 


\section{AGRICULTURAL AND FOOD SCIENCE IN FINLAND}

Vol. 5 (1996): 329-350.

The onset of late blight has been closely monitored in recent years at seven sites in Finland, as part of a Nordic observation network established in 1992. Results from this monitoring network have been used to develop a simple index of blight onset based on a daily temperature sum cumulated on wet days (Kaukoranta 1996). This index has been coupled to a tuber growth model simplified from the more detailed model of MacKerron and Waister (1985). The model computes potential daily tuber growth based on radiation and temperature, assuming that water and nutrients are not limiting. The coupled model is first run through to harvest to compute the potential tuber yield assuming no blight symptoms. Subsequently, the model is run again, this time calculating the date of onset of blight symptoms, whereupon the leaf area index is reduced to zero over a two week period, thus curtailing tuber growth. The difference between the accumulated tuber growth from the date of first symptoms until harvest and the blight-affected tuber growth represents the potential tuber loss due to the disease. More details of the site validation of this model for Finnish conditions are given by Kaukoranta (1996).

A key requirement in applying the model to the grid was for daily temperature and precipitation data, to define the onset of blight. Realistic daily values could not be obtained by interpolating the gridded mean monthly values, so instead the stochastic weather generator, CLIGEN, was used to produce daily climatic time series.

To test the validity of using CLIGEN, the model was first tested for individual meteorological stations in Finland to compare results based on the stochastically generated weather with those based on observed weather during 1961-1990. The analysis revealed that the weather generator underestimates the inter-annual variability of climate on a seasonal basis because it fails to replicate accurately the persistence of weather events such as warm spells and droughts. As a result, while the mean of modelled tuber loss was similar in both cases, the variance based on generated weather was lower than that simu- lated for the observed conditions. Thus, results from the grid should be interpreted as conservative estimates of tuber loss - the actual variability of losses is likely to be greater than depicted.

The parameters of CLIGEN were interpolated to each grid box location, and 30-year time series of baseline and scenario climate were generated for all boxes across the grid. All three SILMU policy scenarios were simulated for 2020, 2050 and 2100.

\section{Results}

Given the numerous models applied to the grid system, and the multiplicity of scenarios examined, it is only possible in this paper to provide a short synthesis of the major results obtained. More detailed findings are published elsewhere (e.g. Carter and Saarikko 1995, 1996).

At the outset, it should be stressed that the mapped results obtained in this study are preliminary and are designed to be illustrative. The maps depict patterns of crop potential that are climatically determined, and do not account for factors such as the local soils, land cover and terrain. Over large regions these factors would preclude crop production altogether. Methods of identifying and excluding such regions from analysis are currently being addressed.

\section{Regional suitability of spring cereals}

Three aspects of the regional suitability for cereals under changing climate are summarised in this section: changes in crop risk and reliability, shifts in patterns of suitability and changes in rates of phenological development. Uncertainties associated with all of these are considered in a later section.

Changes in crop risk and reliability. As climate warms, so the probability of modelled crops reaching the yellow ripening stage increases. In 


\section{AGRICULTURAL AND FOOD SCIENCE IN FINLAND}

Carter, T. R. et al.: Assessing regional crop potential under a changing climate in Finland

CULTIVATED AREA IN 1990

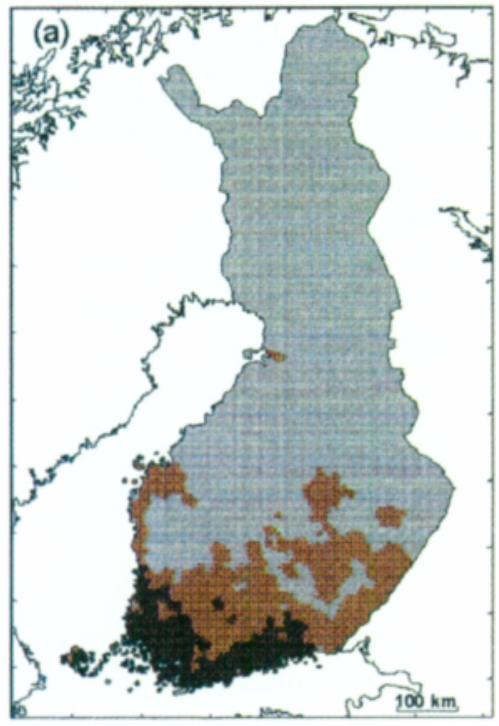

RELIABILITY: BASELINE

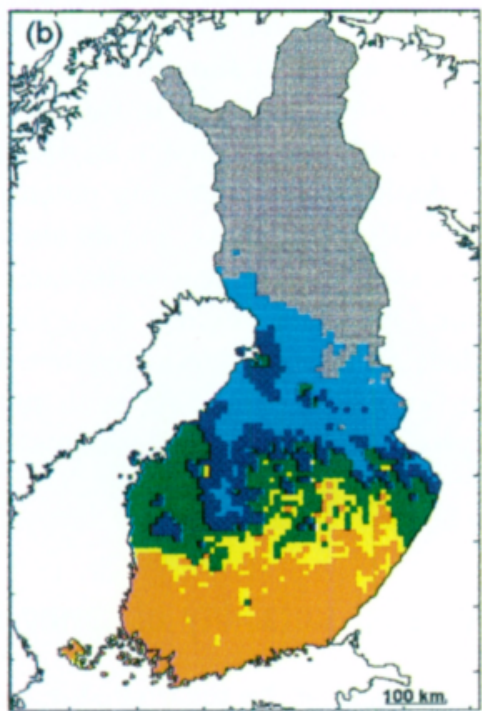

Probability of ripening (percent)

$$
\text { Percent of arable }
$$

$0.0-0.9$
$1.0-9.9$
$\geq 10.0$

RELIABILITY: 2050

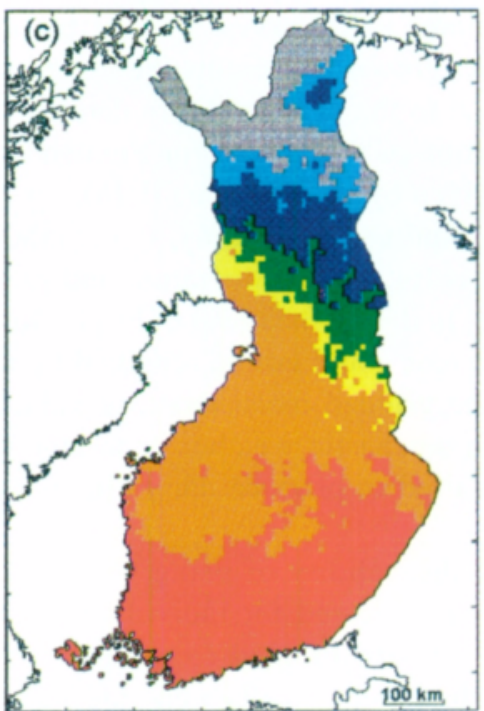

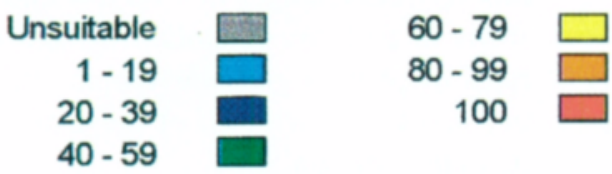

Fig. 3. (a) Actual cultivated area of spring wheat in 1990 as a percentage of total arable (source: Finnish Board of Agriculture); (b and c) estimated probability of successful ripening (percent) for cv. Ruso under the baseline, 1961-1990 climate (b) and SILMU scenario 1 (best guess) by 2050 (c). 


\section{AGRICULTURAL AND FOOD SCIENCE IN FINLAND}

Vol. 5 (1996): 329-350.

cereals, the importance of reaching this stage depends on the final use of the crop. For example, reliable attainment of full maturity is more important on farms where good quality cereal production represents a major source of income, than on farms where it merely supplements other activities.

The estimated regional probability of ripening for an early-maturing spring wheat cultivar (cv. Ruso) is shown in Figure 3b for the baseline climate. As might be expected, the reliability of wheat cropping is greatest in the warmer south of Finland and declines northwards. This map can be compared to the actual pattern of cultivation for all spring wheat varieties in 1990 (Figure 3a), which is representative of the average present-day distribution. The northernmost cultivation areas are approximately coincident with the $60 \%$ probability limit, while the zone of most intensive cultivation $(\geq 10 \%$ of total arable area) coincides with a reliability well in excess of $80 \%$. For barley and oats, the corresponding probabilities are lower, probably reflecting the lower dependence on ripening for these crops.

Figure $3 \mathrm{c}$ illustrates the corresponding probability zones mapped for the climate in 2050 under SILMU scenario 1 (mean annual warming of $\left.2.4^{\circ} \mathrm{C}\right)$. Here, the zone of high $(\geq 80 \%)$ reliability extends into central Finland and there is approximately an even chance of successful ripening in southern Lapland.
Shifts in the pattern of suitability. We have adopted the $80 \%$ probability level to define the limit of suitability for all cereal species in our subsequent analyses, assuming that farmers would be willing to accept a crop "failure" in 2 years out of 10 . Shifts in suitability for each crop have been mapped for 2020, 2050 and 2100 under SILMU scenario 1, relative to the baseline. This is illustrated for barley (cv. Pomo) in Figure 4. The geographical extent of these shifts is summarised in Table 1 for a cultivar of each crop. The shifts can also be interpreted as rates, which are shown as averages at the bottom of Table 1. These imply that under the best guess SILMU scenario the northern limit of reliable cereal cultivation in Finland would shift northwards by, on average, about $45-60 \mathrm{~km}$ per decade up to 2100 .

Changes in the rate of phenological development. Higher temperatures increase the rate of phenological development of cereal crops (cf. Figure 1) so that plants can complete a given phase in a shorter period. Figure 4 demonstrates how the phase heading to yellow ripening in barley (cv. Pomo) progressively shortens as the climate warms under SILMU scenario 1. The duration of this phase is of particular interest, as it contains the grain filling period. A marked foreshortening of the phase would be expected to reduce grain yields, an effect confirmed in simulations with the barley growth model, CropWatN (see below).

Table 1. Estimated shifts in the northern limit of suitability relative to the baseline for cereal cultivars under SILMU scenario 1 (best guess) by 2020, 2050 and 2100, and the mean rate of shift up to 2100 (km/decade).

\begin{tabular}{|c|c|c|c|c|c|c|}
\hline \multirow[t]{2}{*}{$\begin{array}{l}\text { Shifts under SILMU } \\
\text { scenario } 1\end{array}$} & \multicolumn{2}{|c|}{$\begin{array}{l}\text { Spring wheat } \\
\text { (cv. Ruso) }\end{array}$} & \multicolumn{2}{|c|}{$\begin{array}{l}\text { Spring barley } \\
\text { (cv. Arra) }\end{array}$} & \multicolumn{2}{|c|}{$\begin{array}{c}\text { Oats } \\
\text { (cv. Veli) }\end{array}$} \\
\hline & $24^{\circ} \mathrm{E}$ & $29^{\circ} \mathrm{E}$ & $24^{\circ} \mathrm{E}$ & $29^{\circ} \mathrm{E}$ & $24^{\circ} \mathrm{E}$ & $29^{\circ} \mathrm{E}$ \\
\hline $2020(\mathrm{~km})$ & 150 & 150 & 90 & 290 & 130 & 280 \\
\hline $2050(\mathrm{~km})$ & 270 & 460 & 230 & 340 & 280 & 500 \\
\hline $2100(\mathrm{~km})$ & 550 & 640 & 490 & 620 & 550 & 630 \\
\hline $\begin{array}{l}\text { Mean rate to } 2100 \\
(\mathrm{~km} / \text { decade })\end{array}$ & 50 & 58 & 45 & 56 & 50 & 57 \\
\hline
\end{tabular}




\section{AGRICULTURAL AND FOOD SCIENCE IN FINLAND}

Carter, T. R. et al.: Assessing regional crop potential under a changing climate in Finland

2020

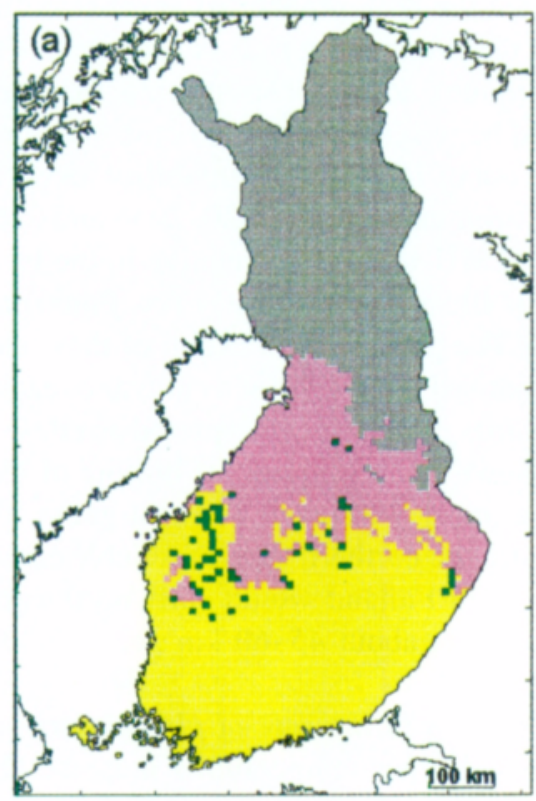

Change in duration

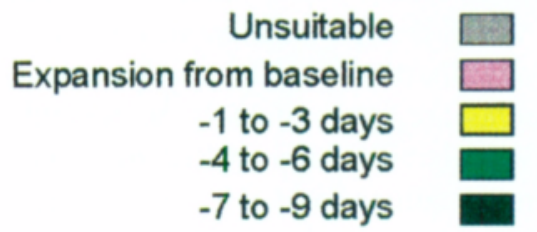

2050

2100
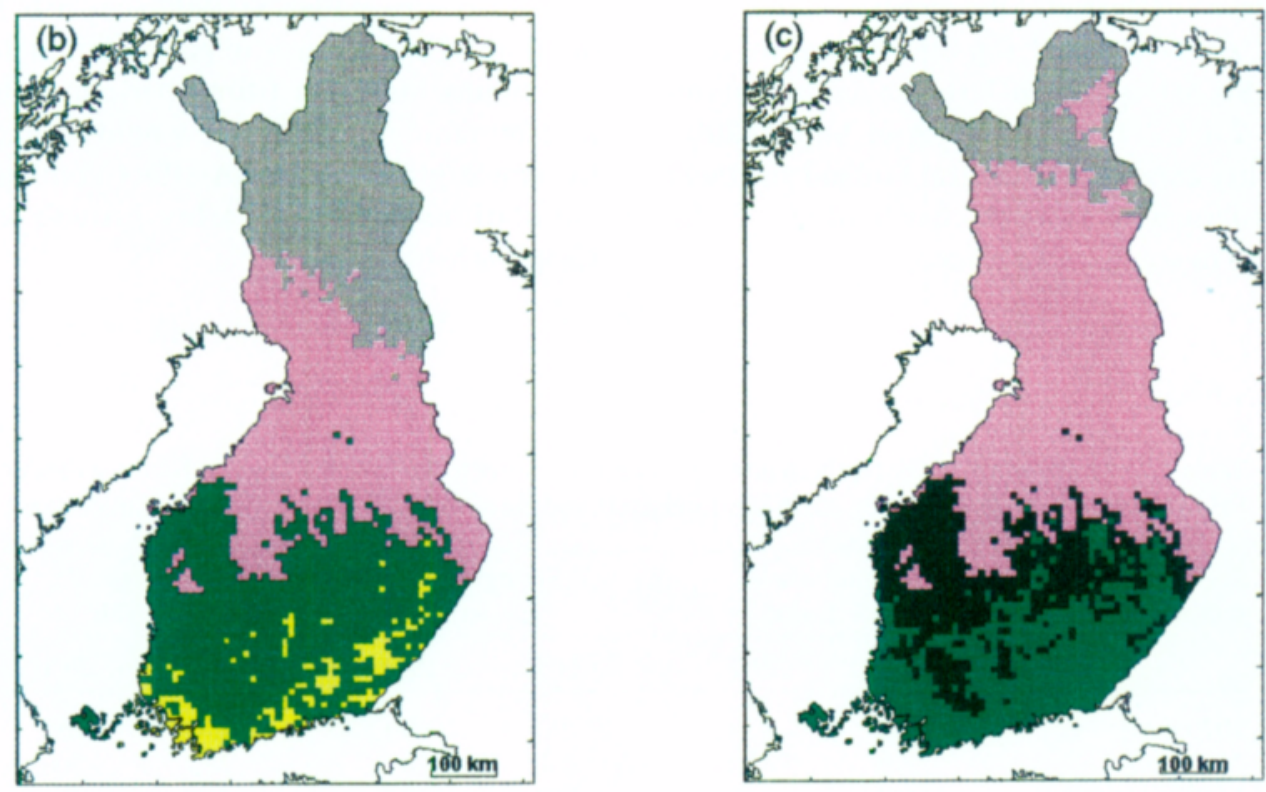

Fig. 4. Simulated change in duration of the phase heading to yellow ripening in barley (cv. Pomo) relative to the 1961-1990 baseline for SILMU scenario 1 (best guess) by (a) 2020, (b) 2050 and (c) 2100. Units are days and areas of expanded suitability are also shown. 
Vol. 5 (1996): 329-350.

\section{Changes in regional cereal yields: the case of barley}

The results presented in this section are for barley. However, given the similarities of growth habit between spring-sown barley, wheat and oats in Finland, the regional pattern of response to climate change shown here can be regarded as broadly indicative of responses for all three cereals - only the specific location and details of changes differ.

Simulations with the CropWatN model used the phenological development model for barley (cv. Pomo) mapped above and similar methods to compute sowing and harvest dates. Here, the modelled estimates of dry matter yield within the zones of suitability (i.e. $80 \%$ reliability) are reported for both stressed and unstressed crops.

Estimates of the 30-year mean potential grain yield for the baseline period are about twice those reported from agricultural districts in annual statistical yearbooks, which is not surprising given that nutrients and water were unlimiting in these runs. Simulated baseline yields for a fine sand soil were close to the potential values, an unrealistic result which is probably attributable to inappropriate selection of soil parameters as described earlier. In contrast, the mean yields estimated for a heavy clay soil (Figure 5a), including water limitations and assuming an annual nitrogen fertilizer application of $100 \mathrm{~kg} / \mathrm{ha}$, are much closer in magnitude to those reported operationally in Finland. Note, however, that since a uniform heavy clay soil is assumed over the whole country, the regional pattern of modelled yields cannot be compared with the actual yields, on a range of soils, reported from different parts of the country. The pattern depicted indicates the highest yields in east-central Finland, declining to the north, mainly as a function of low temperature, and towards the western coast, where the mean growing season soil water deficit is greatest.

To compare the relative effects of increasing $\mathrm{CO}_{2}$ concentration and of changing climate according to SILMU scenario 1 by 2050 , both were analysed separately and then in combination.
Figure 5b shows the modelled mean yield for temperature and precipitation changes alone. Climate change alone has a negative effect on the yield of the Pomo barley cultivar over the whole of southern Finland (compare with Figure $5 \mathrm{a}$ ). This is primarily due to the shortening of the grain filling phase under the increased temperatures (cf. Figure 4), although increased precipitation (by $6 \%$ in the summer months under this scenario) serves to modify this effect. Further north, however, the higher temperatures are beneficial for this variety of barley, enhancing yields and shifting the northern limit of reliability some $300 \mathrm{~km}$ northwards.

The yield response to elevated $\mathrm{CO}_{2}$ (523 ppm) alone, assuming no change in the climate, is positive (less than $1 \mathrm{t} / \mathrm{ha}$ ) with little variation across the country (not shown here). The combined effects of increased $\mathrm{CO}_{2}$ and climate change are shown in Figure $5 \mathrm{c}$. Yield responses are positive across the whole country, with the beneficial effect of increasing $\mathrm{CO}_{2}$ slightly outweighing the negative effect of higher temperatures in southern Finland. The pattern of changes for both the potential and fine sand simulations are very similar to those for clay, but the magnitude of changes is proportionally greater since crops experience little or no water and nutrient stress in these simulations.

Estimates of the inter-annual variation of yields were also obtained. The standard deviation of modelled annual yields on heavy clay under the present-day climate ranges from about $1 \mathrm{t} / \mathrm{ha}$ in the south of Finland to approximately $2 \mathrm{t} / \mathrm{ha}$ at the northern limit of reliability. This decreases under the 2050 scenario over much of southern and central Finland and increases slightly in the extreme south as well as in some northern regions which were unsuitable under the baseline climate.

\section{Changes in pest and disease risk of potato}

Potato cultivation in Finland extends north of the Arctic Circle, but yields are constrained by the short growing season as well as occasional drought during the period of growth. Potato sel- 
Carter, T. R. et al.: Assessing regional crop potential under a changing climate in Finland

\section{BASELINE}

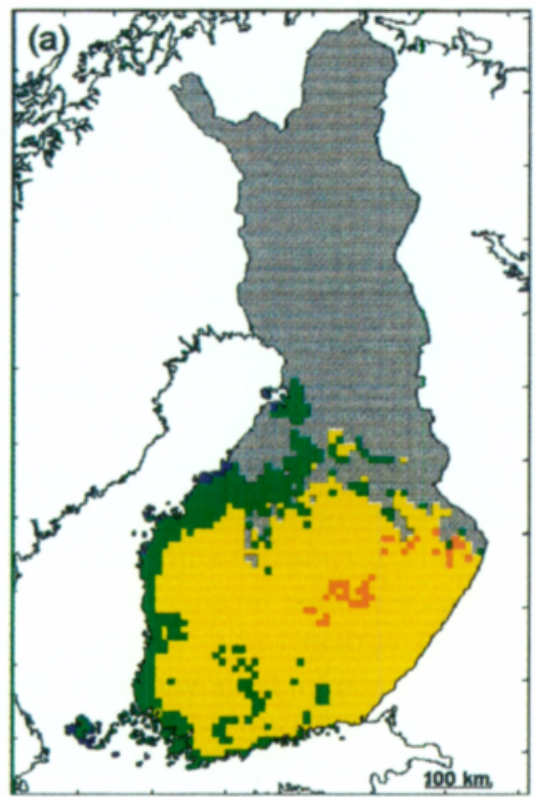

Yield (tha)

Unsuitable
$2.0-2.5$
$2.5-3.0$
$3.0-3.5$
$3.5-4.0$
$4.0-4.5$
$4.5-5.0$

2050: CLIMATE CHANGE ONLY

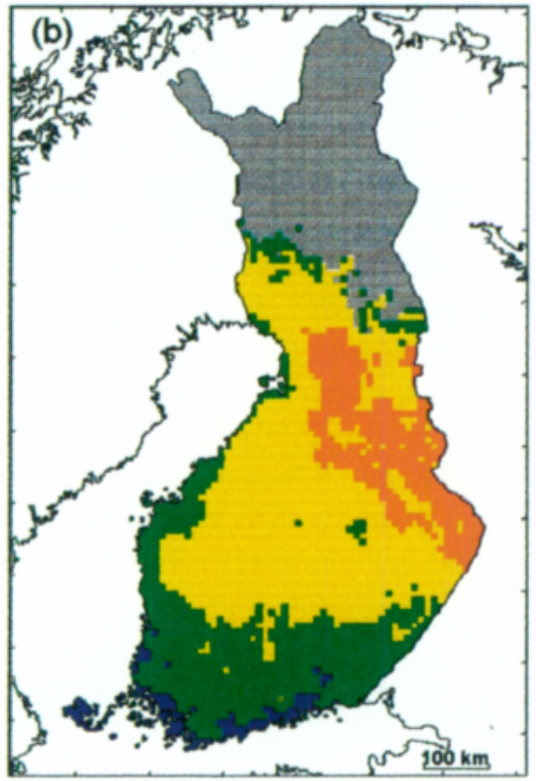

2050: CLIMATE + $\mathrm{CO}_{2}$ CHANGE

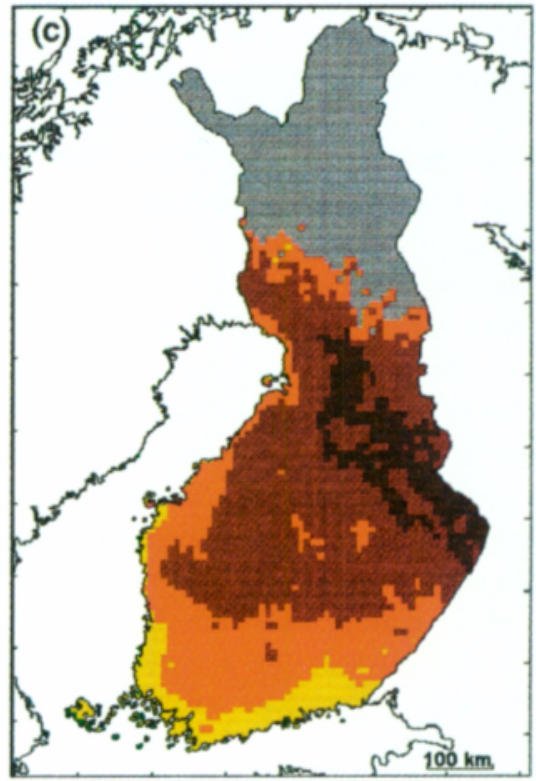

Fig. 5. Modelled grain yield of barley (cv. Pomo) on a heavy clay soil (t/ha) under (a) the baseline climate, 1961-1990,

(b) SILMU scenario 1 (best guess) by 2050 for climate (temperature and precipitation) change only, and (c) SILMU scenario 1 for climate and $\mathrm{CO}_{2}$ changes combined. 


\section{AGRICULTURAL AND FOOD SCIENCE IN FINLAND}

Vol. 5 (1996): 329-350.

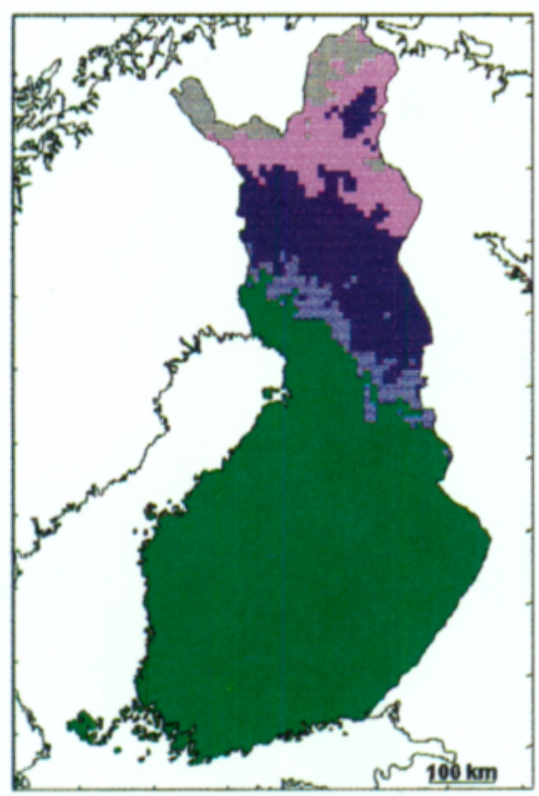

\section{Unsuitable \\ Baseline suitability \\ Expansion by 2050: SILMU low Expansion by 2050: SILMU central Expansion by 2050: SILMU high}

Fig. 6. Potential distribution of the potato cyst nematode (Globodera rostochiensis) based on temperature (median limit) under the baseline climate, 1961-1990, and its extension by 2050 under three alternative future climates: SILMU low, central (best guess) and high policy scenarios.

dom reaches physiological maturity anywhere in Finland under the present-day climate, its growth usually curtailed in the autumn by frost or surplus soil water. Results from the coupled late blight/potential tuber growth model indicate that for the warming by 2050 under SILMU scenario 1 (central), the crop would reliably reach full maturity in the south of Finland before low temperatures became a risk for harvesting. For this reason, in spite of an earlier sowing date, the growing period would actually shorten by about 10 days for present-day cultivars of potato. In contrast, the growing period would extend by 3 4 weeks in the north of the country. Under this scenario, potential dry matter tuber yields increase by some $3-4 \mathrm{t} / \mathrm{ha}$ (about $20-30 \%$ ) in southern Finland and by more than $5 \mathrm{t} / \mathrm{ha}$ in some central and northern areas, where little growth is possible under the baseline climate. However, soil moisture and $\mathrm{CO}_{2}$ effects still need to be incorporated in the model before a more realistic pattern of response can be obtained.
While the prospects for potato yields appear favourable under a warming, the potential for pest and disease damage of the crop also increases. Under SILMU scenario 1 (2050), the northern limit of the potato cyst nematode (the median limit during the 30 years simulated) extends on average by about $250 \mathrm{~km}$ northwards from its location under the baseline climate, occupying many of the areas of current seed production in Lapland (Figure 6). Under SILMU scenarios 2 and 3 (low and high), northward shifts by 2050 average about $50 \mathrm{~km}$ and $400 \mathrm{~km}$, respectively.

The effect of future warming on the potential development of the Columbian root-knot nematode, were it to be introduced in Finland, is no less significant. The model results suggest that under the baseline climate this species would be capable of producing one full generation and hatching a second over much of southern and central Finland (Figure 7a). In warmer years such as 1975 and 1988, it could complete a second generation and hatch a third in the most favour- 
Carter, T. R. et al.: Assessing regional crop potential under a changing climate in Finland

BASELINE

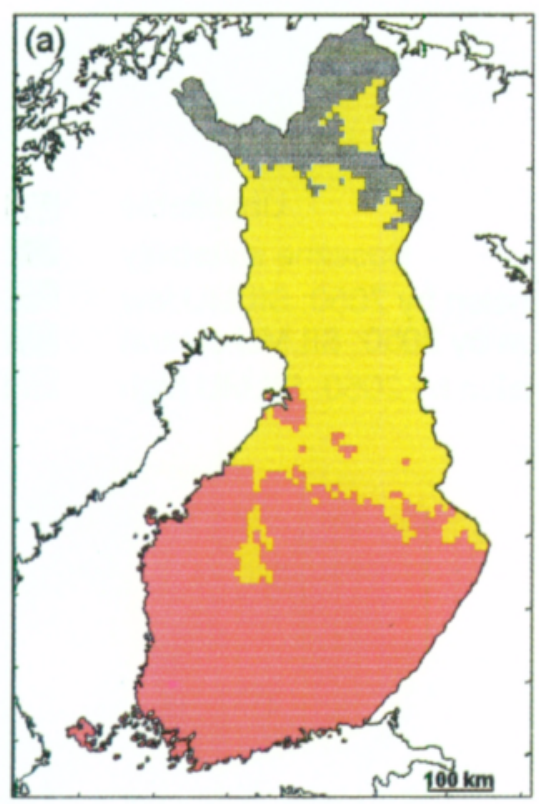

2050

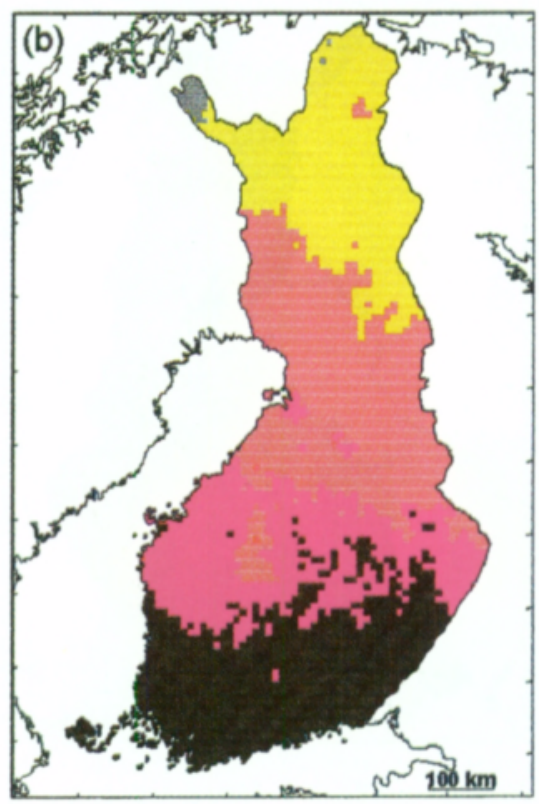

\section{Unsuitable \\ 1st generation completed \\ 2nd generation hatched \\ 2nd generation completed \\ 3rd generation hatched}

Fig. 7. Potential number of generations of the Columbia root-knot nematode (Meloidogyne chitwoodi) based on temperature under: (a) the baseline climate 1961-1990 and (b) SILMU scenario 1 (best guess) by 2050.

able regions. Under the scenario 1 warming by 2050 , the nematode would be capable in an average year of producing two full generations and hatching a third in southern Finland (Figure 7b), with the possibility in warmer years of completing a third and hatching a fourth generation at a few locations. The damage implications of such changes are self-evident.

Finally, the results of the simulations of potato late blight also indicate an increased risk of occurrence and damage potential for unprotected crops. Figure 8a shows the estimated tuber loss under the baseline climate. This is greatest in the south of Finland, where yields are highest and where blight symptoms, and hence losses, are estimated to occur in most or all years (not shown). Losses are negligible north of the Arctic Circle.

Under SILMU scenario 1 for 2050, the date of onset of blight symptoms is earlier than for the baseline by some 20 days in the south and 30 days in the north. In the absence of crop protection, losses would occur in every year over all of central and southern Finland, and the annual risk of blight is greater than $50 \%$ over most of the remainder of the country. Average tuber losses increase over the whole country relative to the baseline, with the greatest increase in loss 
Vol. 5 (1996): 329-350.

BASELINE

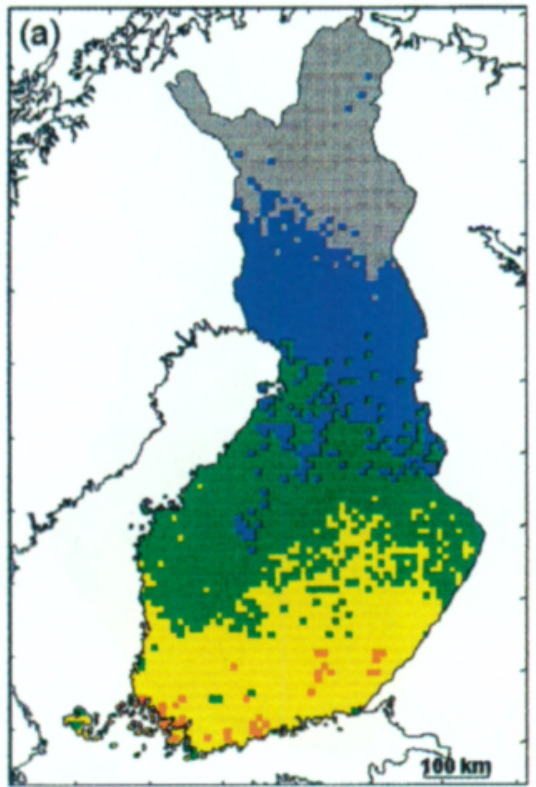

2050

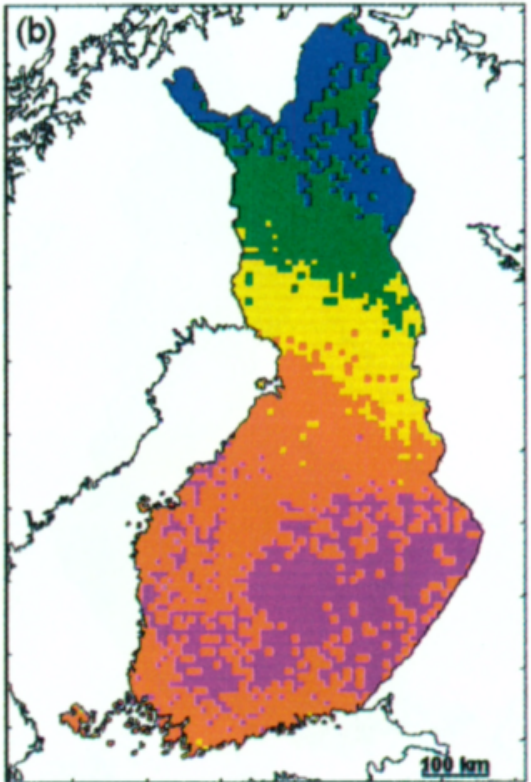

\section{Potential yield loss (t/ha)}

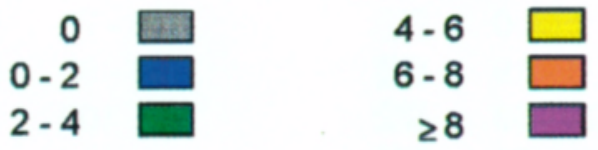

Fig. 8. Simulated potential tuber loss in potato (t/ha) due to late blight (Phytophthora infestans) under: (a) baseline climate, 1961-1990 and (b) SILMU scenario 1 (best guess) by 2050.

occurring in central Finland, where the increases in potential yield are estimated to be largest (Figure 8b). The estimated increase in loss due to late blight is similar in magnitude and may even exceed the simulated increase in tuber yield over much of central and southern Finland, but yield gains outweigh losses in the north.

\section{Changes in the potential for cultivating new crops: the case of maize}

All of the above model simulations pertain to crop varieties that are cultivated at the present- day in Finland. One important conclusion is that as the climate changes, these varieties will become progressively maladapted to the new environment. An obvious farming response is to substitute these with different varieties or even with new species that can properly exploit the changed conditions. One candidate as a substitute crop for a warmer climate is maize, and the model simulations with CERES-Maize were intended to assess the potential for this crop under the changed conditions.

The results of these simulations are summarised in Figure 9. Even in the most favourable areas of the country, a measurable (non-zero) 
Carter, T. R. et al.: Assessing regional crop potential under a changing climate in Finland

BASELINE

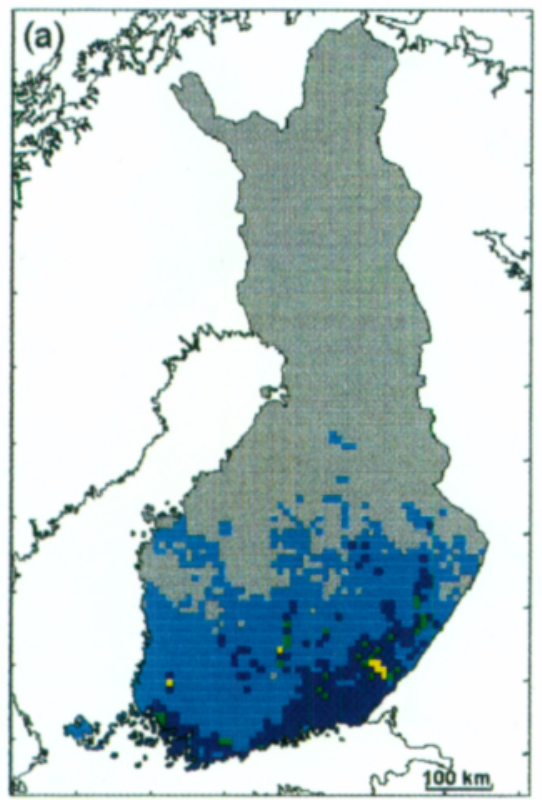

2050

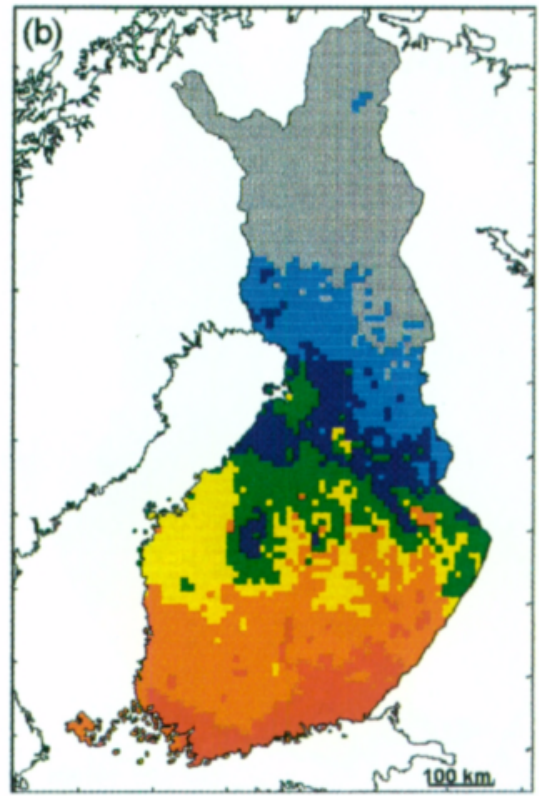

\section{Probability of grain formation (percent)}

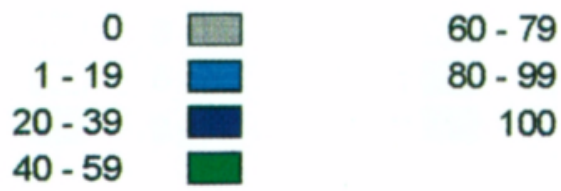

Fig. 9. Simulated probability (percent) of obtaining measurable (non-zero) grain yield of maize under: (a) baseline climate, 1961-1990 and (b) SILMU scenario 1 (best guess) by 2050.

grain yield can only be expected in about 6 years in 10 (Figure 9a). Over most of the country, during most years, the crop would not even reach the grain filling stage of development. 30-year average baseline yields for an unstressed crop are estimated to be about $2 \mathrm{t} / \mathrm{ha}$ at isolated locations in southern Finland, although in favourable years yields as high as $7 \mathrm{t} / \mathrm{ha}$ are simulated. Except for these rare instances, however, it is unlikely that the grain yield would be of a sufficient quality for any use other than green fodder or silage.

Under the temperature changes given by SIL-
MU scenario 1 by 2050 , the probability of obtaining a non-zero grain yield is estimated to have increased to $100 \%$ in southern Finland, and measurable yields could be obtained in over $50 \%$ of years as far north as Oulu (Figure 9b). The mean level of potential maize yields estimated under this scenario exceeds $7 \mathrm{t} / \mathrm{ha}$ in the most favourable areas (10 t/ha in warm years), with yields averaging $4 \mathrm{t} / \mathrm{ha}$ or more over a sizable part of southern Finland. The effects of increasing $\mathrm{CO}_{2}$ concentrations on crop photosynthesis, which are not modelled here, are likely to be much lower for a crop like maize, with a $\mathrm{C}_{4}$ pho- 


\section{AGRICULTURAL AND FOOD SCIENCE IN FINLAND}

Vol. 5 (1996): 329-350.

tosynthetic pathway, than for $\mathrm{C}_{3}$ crops like barley and potato (e.g. see Reilly et al. 1996). $\mathrm{CO}_{2}$ and water stress effects will be investigated in further work with the model.

\section{Quantifying the uncertainties}

We have presented results from a diverse set of models and for a range of climatic scenarios. The results are preliminary, and all are subject to uncertainties. In an attempt to quantify some of these uncertainties, four sources of uncertainty have been identified and compared using the development model for spring wheat (cv. Ruso) described earlier: cultivar type, model error, global scenario assumptions, and regional scenario differences.

Cultivar type. The response of a given crop species to climate varies widely among different cultivars of that crop, a diversity that forms the whole basis of plant breeding. The differences in response of two cultivars of wheat (Ruso and Kadett), chosen to represent the range of growth traits in Finnish cultivars, are shown in Figure 10a. Though this is not strictly a measure of uncertainty, it does indicate what range of responses are implied when generalising the behaviour of individual crop species.

Model errors. The quantification of model errors and uncertainties is perhaps the single most difficult and time consuming task in model testing. However, the importance of such exercises cannot be overstated, as the credibility of the results depends upon a good knowledge of model accuracy.

Here we use as a simple example the phenological models for cereals described above. The uncertainty of the linear relationship between temperature and development rate is delimited as $95 \%$ confidence limits around the regression line in Figure 1 (dashed lines). These confidence limits can be expressed geographically as uncertainties in the limits of suitability (Figure 10b). Compared to the differences between cultivars (Figure 10a), this source of uncertainty appears fairly modest. However, if the uncertainty of any single point plotted in Figure 1 were to be evaluated, the plotted and mapped range of uncertainty would be much greater. Wider uncertainty ranges than shown in Figure 10b would also be expected for results from the other models described in this paper, were they to be evaluated.

Global scenario assumptions. By far the greatest source of uncertainty in the estimates of future crop potential shown here is attributable to the range of SILMU temperature scenarios. This range accounts for uncertainties at the global level of both greenhouse gas emissions into the atmosphere and the mean climate response to changing atmospheric composition (Carter 1996). The magnitude of the uncertainty range is illustrated in Figure 10c, which shows the shift in suitability of spring wheat (cv. Ruso) by 2050 for each of the SILMU policy scenarios (low, central and high). The range of estimates varies from a low estimate averaging about 100 $\mathrm{km}$ under scenario 2 , to a high estimate of about $550 \mathrm{~km}$ under scenario 3. Similar results are also obtained for the other cereal crops.

Regional scenario differences. The SILMU policy scenarios only express the uncertainties at global level. There are further uncertainties to consider at a regional level, some of which are represented in the SILMU scientific scenarios. These are based on alternative regional patterns of temperature change specified by general circulation models (Carter 1996). The effect of this source of uncertainty on crop suitability is shown in Figure 10d. Differences in the limits of suitability under alternative regional climate predictions appear to be of the same order of magnitude as corresponding differences assuming alternative crop cultivars (Figure 10a).

\section{Discussion}

The major findings of this study can be summarised as follows:

1) A warming of the climate is estimated to induce shifts in the northern limit of cereal cul- 


\section{AGRICULTURAL AND FOOD SCIENCE IN FINLAND}

Carter, T. R. et al.: Assessing regional crop potential under a changing climate in Finland

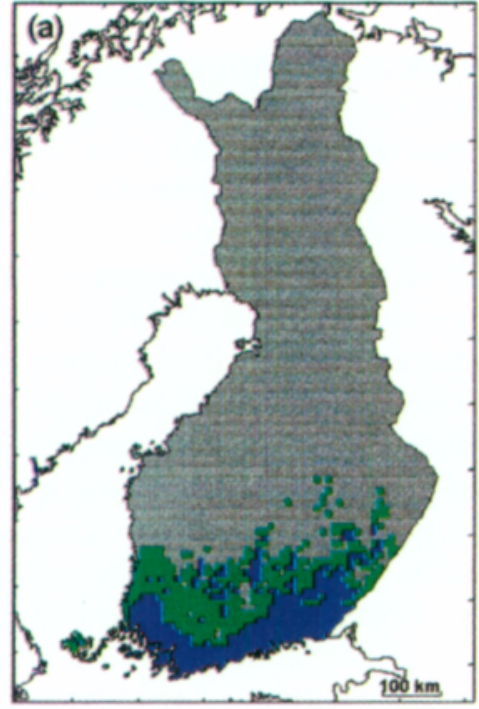

Unsuitable Suitable (Ruso)

Suitable (Ruso \& Kadett)

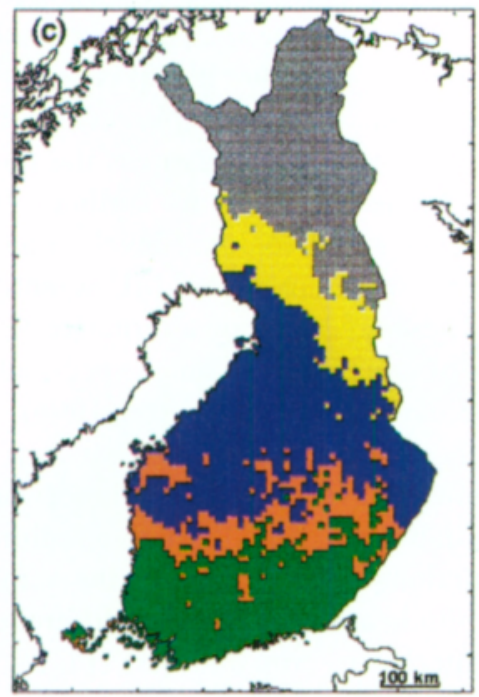

Unsuitable

Baseline suitability

Extension SILMU low

Extension SILMU central

Extension SILMU high
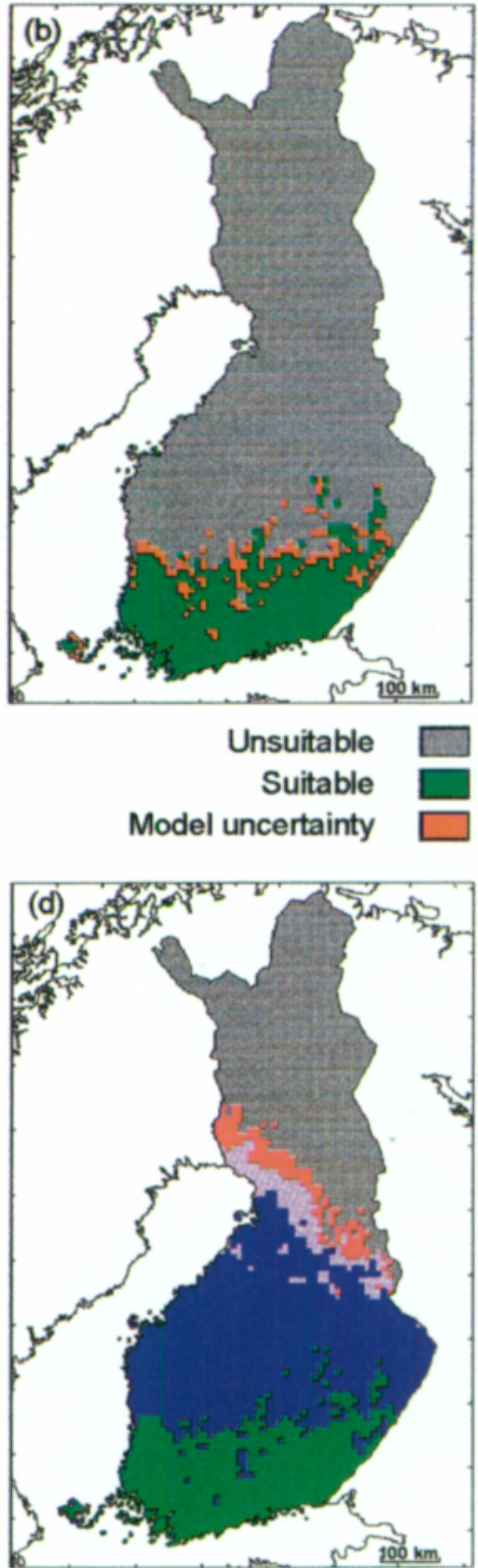

Unsuitable

Baseline suitability

Exten. MPI, GFDL, UKTR

Extension GFDL, UKTR Extension UKTR

Fig. 10. Range in estimates of suitability for spring wheat (cv. Ruso) attributable to: (a) cultivar type (Ruso and Kadett under the baseline climate), (b) uncertainty of the development model (baseline climate), (c) uncertainties in projections of global climate change (extension under the SILMU low, central and high policy scenarios by 2050) and (d) uncertainties in projections of regional climate change (extension under the SILMU scientific scenarios - GFDL, UKTR and MPI by 2050). For explanation see text. SILMU scenarios are described in Carter (1996). 
Vol. 5 (1996): 329-350.

tivation of between 100 and $150 \mathrm{~km}$ per ${ }^{\circ} \mathrm{C}$ increase in mean annual temperature. Under the best guess SILMU scenario, this translates into a mean northward shift of about $50 \mathrm{~km}$ per decade up to 2100 .

2) Average grain yields of present-day barley cultivars in 2050 are estimated to be greater than at present over the whole country, with the greatest increases in north-central Finland under the best guess SILMU scenario for a combination of changed climate and increased $\mathrm{CO}_{2}$ concentration. However, increased temperature alone has a negative effect on yields in southern Finland, due to a shortened grain filling period.

3) The risk of crop damage by pests and diseases increases in all regions under a warming of the climate. Northward shifts in the distribution of certain pests could be of a similar magnitude and rate as reported above for cereal crops. Additional generations of multivoltine pest species can also be expected. The damage potential of diseases such as potato late blight could increase at a similar rate as the potential increase in yields of the crop host.

4) The opportunities for cultivating new crops in Finland could increase under a warmer climate. Estimates suggest that grain maize could be cultivated reliably by 2050 in many parts of southern Finland under the best guess SILMU scenario.

5) Uncertainties surround all of these estimates. The largest uncertainty is that attributable to estimates of future climate, but other uncertainties to consider include model errors and assumptions, observation errors, and alternative modelling methods.

The results represent an early attempt at depicting the regional effects of climate change on Finnish agriculture. Considerable efforts are still required to refine the methods and to improve the models. Future research efforts should concentrate on the following areas:

- Further testing and validation of existing models, to establish their credibility when applied in climate change studies. In addition to rigorous sensitivity analyses, this also re- quires the acquisition of validation material from controlled experiments and from regions with a warmer climate than in Finland

- Refining methods of scaling-up from site models to the regional-scale, including improving methods of spatial model validation, analysing and depicting uncertainty and testing and applying stochastic weather generators.

- Improving the realism of crop potential mapping, by accounting for local features of land cover, soils and topography which may preclude arable agriculture altogether.

- Widening the focus to consider climate change effects on other crop species, including the major food and non-food crops currently grown and those potentially viable under a changed climate. Models will need to be tested for each crop considered.

- Considering more aspects of farm-level adaptation to changing climate, for example, adjustments in fertilizer application, timing of operations, crop switches and irrigation. The effects of all of these can be simulated with appropriate models.

- Evaluating the effects of climate change on crop quality. There are many measures of quality, and most can be related to seasonal weather. $\mathrm{CO}_{2}$ concentration is also known to affect some aspects of crop quality.

Clearly there is much work still to be done if we are to obtain a more comprehensive and accurate picture of agricultural potential in Finland under the changing climate of the next century.

Acknowledgements. We are grateful to a number of colleagues for supplying models and advice: Jouko Kleemola of Kemira Oy, Espoo, provided the computer code of CropWatN and much assistance in calibrating the model. Timo Kaukoranta and Kari Tiilikkala of the Crop Protection Department, Agricultural Research Centre of Finland, Jokioinen, offered the potato late blight and nematode models, respectively. We also thank Eino Hellsten and Ari Venäläinen of the Finnish Meteorological Institute for setting up the interpolation routines for climatological data. This work was funded by the Academy of Finland as part of the Finnish Research Programme on Climate Change (SILMU). 
Carter, T. R. et al.: Assessing regional crop potential under a changing climate in Finland

\section{References}

\begin{abstract}
Agricultural Information Centre 1994. Agrifacts '94 about Finland. Helsinki. $31 \mathrm{p}$.

Bindi, M., Castellani, M. Marrachi, G. \& Miglietta, F. 1993. The ontogenesis of wheat under scenarios of increased air temperature in Italy: a simulation study. European Journal of Agronomy 4: 261-280.
\end{abstract}

Brignall, A.P., Favis-Mortlock, D.T., Hossell, J.E. \& RounsevelI, M.D.A. 1994. Climate change and crop potential in England and Wales. Journal of the Royal Agricultural Society of England 155: 140-161.

Brooks, C.E.P. 1943. Interpolation tables for daily values of meteorological elements. Quarterly Journal of the Royal Meteorological Society 69: 160-162.

Carter, T.R. 1996. Developing scenarios of atmosphere, weather and climate for northern regions. Agricultural and Food Science in Finland 5: 235-249 (this issue).

-, Parry, M.L. \& Porter, J.H. 1991a. Climatic change and future agroclimatic potential in Europe. International Journal of Climatology 11: 251-269.

-, Porter, J.H. \& Parry, M.L. 1991b. Climatic warming and crop potential in Europe. Global Environmental Change 1: 291-312.

-, Posch, M. \& Tuomenvirta, H. 1995. SILMUSCEN and CLIGEN user's guide: Guidelines for the construction of climatic scenarios and use of a stochastic weather generator in the Finnish Research Programme on Climate Change (SILMU). Publications of the Academy of Finland $5 / 95$, Helsinki. 60 p. plus diskette.

- \& Saarikko, R. 1995. Effects on spring wheat and spring barley in Finland. In: P.A. Harrison et al. (eds.). Climate Change and Agriculture in Europe: Assessment of Impacts and Adaptation. Research Report No. 9, Environmental Change Unit, University of Oxford. p. 319-330.

- \& Saarikko, R.A. 1996. Estimating regional crop potential in Finland under a changing climate. Agricultural and Forest Meteorology 79: 301-313.

Davies, A., Shao, J., Brignall, P. \& Bardgett, R. 1993. Effect of climatic change on maize production. In: D. Wilson (ed.). Crop Adaptation to Cool, Wet, Climates. COST 814 Workshop, Aberystwyth, UK. p. 29-33.

Hakala, K. \& Mela, T. 1996. The effects of prolonged exposure to elevated temperatures and elevated $\mathrm{CO}_{2}$ levels on the growth, yield and dry matter partitioning of field-sown meadow fescue. Agricultural and Food Science in Finland 5: 285-298 (this issue).

Henttonen, H. 1991. Kriging in interpolating July mean temperatures and precipitation sums. Reports from the Department of Statistics 12/1991, University of Jyväskylă, Finland. $41 \mathrm{p}$.

Ilola, A., Elomaa, E. \& Pulli, S. 1988. Testing of a Danish growth model for barley, turnip rape and timothy in Finnish conditions. Journal of Agricultural Science in Finland 60: 631-660.

Jones, C.A. \& Kiniry, J.R. 1986. (eds.). CERES-Maize. A simulation model of maize growth and development. Texas A\&M University Press, College Station, Texas. $204 \mathrm{p}$.

Jones, M.B. \& Carter, T.R. 1993. European grassland production in a changing climate. Proceedings of the 14th General Meeting of the European Grassland Federation, Lahti, Finland. p. 97-110.

Karvonen, T. \& Kleemola, J. 1995. CROPWATN: Production of water and nitrogen limited crop production. In: B. Kabat et al. (eds.). Modelling and Parameterization of the Soil-Plant-Atmosphere System: A Comparison of Potato Growth Models. Wageningen pers, Wageningen, The Netherlands. p. 335-369.

Kaukoranta, T. 1996. Impact of global warming on potato late blight: risk, yield loss and control. Agricultural and Food Science in Finland 5: 311-327 (this issue).

Kenny, G.J. \& Harrison, P.A. 1992a. Thermal and moisture limits of grain maize in Europe: model testing and sensitivity to climate change. Climate Research 2:113129.

- \& Harrison, P.A. 1992b. The effects of climate variability and change on grape suitability in Europe. Journal of Wine Research 3: 163-183.

-, Harrison, P.A., Olesen, J.E. \& Parry, M.L. 1993. The effects of climate change on land suitability of grain maize, winter wheat and cauliflower in Europe. European Journal of Agronomy 4: 325-338.

Kettunen, L., Mukula, J., Pohjonen, V., Rantanen, O. \& Varjo, U. 1988. The effects of climatic variations on agriculture in Finland. In: M.L. Parry et al. (eds.). The Impact of Climatic Variations on Agriculture. Volume 1. Assessments in Cool Temperate and Cold Regions, Kluwer, Dordrecht, The Netherlands. p. 511-614.

Kleemola, J. \& Karvonen, T. 1996. Modelling growth and nitrogen balance of barley under ambient and future conditions. Agricultural and Food Science in Finland 5: 299-310 (this issue).

Leemans, R. \& Solomon, A.M. 1993. Modeling the potential change in yield and distribution of the earth's crops under a warmed climate. Climate Research 3: 79-96.

Mackerron, D.K.L. \& Waister, P.D. 1985. A simple model of potato growth and yield. Part 1. Model development and sensitivity analysis. Agricultural and Forest Meteorology 34: 241-252.

Mearns, L.O., Rosenzweig, C. \& Goldberg, R. 1992. The effect of changes in interannual climatic variability on CERES-Wheat yields: sensitivity and $2 \times \mathrm{CO}_{2}$ studies. Agricultural and Forest Meteorology 62: 159-189.

Parry, M. 1990. Climate change and world agriculture. Earthscan, London. 157 p.

Posch, M. 1992. Development of a weather generator for Finland. In: M. Kanninen \& P. Anttila (eds.). The Finnish Research Programme on Climate Change. Progress Report. Publications of the Academy of Finland 3/92, Helsinki. p. 245-249.

- 1994. Development of a weather generator for Finland II. In: M. Kanninen \& P. Heikinheimo (eds.). The Finnish Research Programme on Climate Change. Second Progress Report. Publications of the Academy of Finland 1/94, Helsinki. p. 323-328.

Pulli, S., Tigerstedt, P.M.A., Kara, O. \& Brüninghaus, G. 1979. Adaptation of silage maize varieties under ex- 


\title{
AGRICULTURAL AND FOOD SCIENCE IN FINLAND
}

\author{
Vol. 5 (1996): 329-350.
}

treme northern growing conditions in Finland. Journal of the Scientific Agricultural Society of Finland 51: 197-209. Reilly, J. (and 22 others). 1996. Agriculture in a changing climate: impacts and adaptation. In: R.T. Watson et al. (eds.). Climate Change 1995: Impacts, Adaptation and Mitigation Options: Scientific-Technical Analyses. Contribution of Working Group II to the Second Assessment Report, Intergovernmental Panel on Climate Change, Cambridge University Press, Cambridge and New York. p. 427-467.

Rosenzweig, C. \& Iglesias, A. 1994. Implications of climate change for international agriculture: crop modeling study. EPA 230-B-94-003, Office of Policy Planning and Evaluation, United States Environmental Protection Agency, Washington, D.C.

- \& Parry, M.L. 1994. Potential impact of climate change on world food supply. Nature 367: 133-138.

Rötter, R.P. \& van Diepen, C.A. 1994. Rhine basin study: Land use projections based on biophysical and socioeconomic analyses. Volume 2. Climate change impact on crop yield potentials and water use. DLO Winand Staring Centre. Report 85.2, Wageningen, The Netherlands. $152 \mathrm{p}$.

Saarikko, R.A. \& Carter, T.R. 1996. Phenological development in spring cereals - response to temperature and photoperiod under northern conditions. European Journal of Agronomy (in press).

Semenov, M.A. \& Porter, J.R. 1995. Climatic variability and modelling of crop yields. Agricultural and Forest Meteorology 73: 265-283.

Solantie, R. 1987. Hallojan loppuminen kevăăllă ja alkaminen syksyllä (English summary: Last spring frosts and first autumn frosts in Finland). Meteorological Publications No. 6, Finnish Meteorological Institute, Helsinki. $60 \mathrm{p}$.

Tiilikkala, K. 1991. Impact of climate and agricultural practices on the pest status of Heteroderoidea nematodes in Finland. Agricultural Research Centre of Finland, Jokioinen, Finland. 43 p. plus reprints. Doctoral Thesis.

-, Carter, T., Heikinheimo, M. \& Venäläinen, A. 1995. Pest risk analysis of Meloidogyne chitwoodi for Finland. EPPO Bulletin 25: 419-435.

Williams, G.D.V., Fautley, R.A., Jones, K.H., Stewart, R.B. \& Wheaton, E.E. 1988. Estimating effects of climatic change on agriculture in Sasakatchewan, Canada. In: M.L. Parry et al. (eds.). The Impact of Climatic Variations on Agriculture. Volume 1. Assessments in Cool Temperate and Cold Regions, Kluwer, Dordrecht, The Netherlands. p. 219-379.

Wolf, J. 1993. Effects of climate change on wheat production potential in the European Community. European Journal of Agronomy 4: 281-292.

- \& van Diepen, C.A. 1995. Effects of climate change on grain maize yield potential in the European Community. Climatic Change 29: 299-331. 
Carter, T. R. et al.: Assessing regional crop potential under a changing climate in Finland

\title{
SELOSTUS
}

\section{Arviointi Suomen kasvintuotantopotentiaalin alueellisista riskeistä ja epävarmuuksista ilmaston muuttuessa}

\author{
Timothy R. Carter, Riitta A. Saarikko ja Kai J. Niemi \\ Maatalouden tutkimuskeskus
}

Tutkimus selvitti muutamien kasvien alueellista viljelysopivuutta ja potentiaalista sadontuottoa ilmaston muuttuessa Suomessa. Matemaattisia malleja sovellettiin koko Suomen kattavassa $10 \mathrm{~km}$ hilapisteverkossa. Mallien avulla tarkasteltiin erilaisten kevätvehnä-, ohra-, kaura-, peruna- ja maissilajikkeiden kehitystä ja kasvua. Lisäksi selvitettiin perunaruton ja perunan kahden tuhoeläimen, peruna-ankeroisen ja juuren äkämäankeroisen esiintymisriskiä. Tarkastelu tehtiin sekä vertailukauden ilmasto-oloille (19611990) että tulevaisuuden mahdollisille ilmasto-oloille eli skenaarioille, jotka kehitettiin osana Suomalaisen ilmakehänmuutosten tutkimusohjelmaa SILMUa. Tutkimustulokset on esitetty karttoina, joiden tärkeimmät johtopäätökset ovat: (1) Ilmaston lämmetessä viljojen viljelysopivuuden pohjoisraja siirtyy noin $100-150 \mathrm{~km}$ pohjoisemmaksi jokaista yhden asteen vuosikeskilämpötilan nousua kohti. (2) Ilmastonmuutoksesta ja ilman hiilidioksidipitoisuuden kohoamisesta johtuen nykyisin viljeltyjen ohralajikkeiden sadot kasvaisivat koko Suomessa vuoteen 2050 mennessä. (3) Arvioitu ilmaston lämpeneminen siirtää ankeroislajien potentiaalisia esiintymisrajoja pohjoiseen sekä lisää sukupolvien määrää, joita juuren äkämäankeroinen kykenisi vuodessa tuottamaan. Perunan viljelyssä myös ruttoepidemioiden riski lisääntyy. (4) Vuoteen 2050 mennessä maissin viljelvarmuus olisi parantunut niin, että Etelä-Suomen edullisimmilla alueilla jyväsadot olisivat tyydyttäviä. (5) Esitetyt arviot kasvintuotantopotentiaalista ovat epävarmoja, mikä johtuu ilmastoskenaarioista, mallien virheistä ja epätarkkuuksista, oletuksista ja havaintovirheistä. 